\title{
RELIABILITY MODELING AS PRODUCTION QUALITY EVALUATION METHOD INTRODUCTION
}

\section{Grudtsyna Y. V.}

\section{INTRODUCTION}

The quality problem is relevant for all goods and services, and the problem of improving the quality of production takes a leading place in ensuring its competitiveness in the developed countries of the world. Production quality is an important indicator of an enterprise's activities, and improving production quality largely determines the ability of an enterprise to survive in a market. For the Ukrainian economy, the release of highquality products is a strategic task. Only the release of high-quality products will ensure the country's success in both the domestic and foreign markets.

A thorough study requires a quantitative evaluation of production quality, because quality evaluation is an inseparable element of any quality management system, since to control any process, first of all, it is necessary to be able to measure and evaluate its parameters. Among the variety of quality indicators by which it is evaluated, special attention is required to the reliability indicator that characterizes the production in terms of storing its properties over time, because for any consumer it is important how long the product be in use. A particularly important indicator of reliability is for industrial production, in particular industrial equipment, because the reliability of the equipment, that is, work with the least number of failures and consequently inactive time, is one of the elements of the smooth operation of the entire enterprise. Therefore, the issue of evaluating reliability over time is of particular relevance and requires careful study.

Analysis of research and publications. The problem of production quality evaluation has been and remains the object and subject of scientific research. To the study of problematics of production quality evaluation has been given a lot of attention by domestic and foreign experts. Foreign experience in managing and evaluating product quality is reflected in the works of A. Shewhart, K. Ishikawa, G. Taguchi, J. Juran, E. Deming etc. Among domestic scientists were A.M. Krylov, P. Bridgman, G.G. Azgaldov, 
Z.N. Krapyvensky, A.V. Glychev, V.P. Panov, Yu.P. Adler and many other scientists and specialists. In Ukraine, T. Bubela, T. Boyko, P. Stolyarchuk, L.I. Bozhenko, P.Ya. Kalyta, A. Yu. Chorny, G.G. Ushakov, V.R. Kutz, B. Stadnyk, V. Motalo are handling production quality evaluation problems.

Paying tribute to the scientific and practical significance of the works of the above authors, it should be noted that the problems associated with the evaluation of production quality are not fully understood and require further development.

\section{Analysis of the quality evaluation methods and identification of deficiencies}

The purpose of the article is to identify indicators and methods for product quality evaluation, to show their relationship with the needs of consumers and to identify the shortcomings of a modern system of product quality evaluation. As part of the study, the task was set to simulate reliability as the main indicator in the system of quality evaluation indicators.

The solution to the problem of improving product quality requires a clear vision of the understanding of the essence of the concept of "quality". Based on the fact that quality is a capacious and complex category, it has a number of aspects in the literature, you can find many of its formulations. Let's consider the definition of the concept of quality by foreign and domestic scientists, as well as regulatory documents. It is worth noting that the category "quality" was analyzed by Aristotle in the 3rd century BC., saying "what exists by itself, already forms a quality", then in research in the category of "quality" was engaged the philosopher Hegel ${ }^{1}$. A lot of scientific research is devoted to questions of evolution of the development of the concept of production quality. The work of Soviet economists A.V. Glycheva, V.P. Panova, G.G. Azgaldova "What is quality?" is devoted to the research on the essence of quality ${ }^{2}$. In the process of evolution, the concept of quality has undergone changes in the understanding of its essence. In modern conditions, production quality is directly related to meeting the needs of society. That is, the term "quality" has a whole range of interpretations, which is associated with its multiaspect. From a philosophical point of view, quality is understood as a set of properties, thanks to which one object can be distinguished from another.

\footnotetext{
${ }^{1}$ Гегель Г.В.Ф. Логіка. В кн. : Гегель Г.В.Ф. Твори. Т.І.М. - Л.: Держвидав, 1929.

${ }^{2}$ Гличев А.В., Панов В.П., Азгальдов Г.Г. Что такое качество? Москва : Экономика, 1968. 135 с.
} 
In the social aspect, quality is associated with the study of consumer relations to the object, his perception, thoughts and reviews. So, the qualitative properties of products can depend on various factors: cultural (level of education, customs, traditions, fashion) and demographic (gender, age), from changes in supply and demand, from the level of consumer income. It is worth agreeing with the opinion of Soboleva M.A., who notes, that "Direct compliance with the standards provides only a minimum level of product quality" ${ }^{3}$, that is, compliance only with existing drawings, standards, regulatory documents is only one of the signs of product quality and does not conclude the entire content of this the concepts. Economist Syskov V. I. notes that "product quality should be understood as the degree, measure of meeting the demand for this type of product under fixed consumption conditions, which are determined by the totality of characteristics created in the production process in accordance with the requirements of standards"4.

J. M. Juran, a well-known American specialist in quality, speaking about the definition of quality, writes: "The concept of product quality differs from the concept of quality of construction, technology. The first means only the degree of compliance with the drawings, regulations and standards, and the second - the characteristics of the raw materials used, the method of production and control, etc. But compliance with the drawings, specifications and standards characterizes not only the quality of the product as such, but how much the quality of work to achieve it". J. Juran distinguishes among the concepts of quality, product, design, technology and considers quality as suitability for use, that is, compliance with the purpose and degree of customer satisfaction, which cannot be disagreed with in today's conditions ${ }^{5}$.

The views of the scientist Feigenbaum A. regarding the concept of quality also come from the fact that there is a direct relationship between quality and meeting the needs and expectations of consumers. The concept of "quality" is interpreted by scientists from the point of view of full satisfaction of consumer needs ${ }^{6}$.

\footnotetext{
${ }^{3}$ Соболева М.А. Роль стандартизации в решении проблем качества промышленной продукции в США. Экономические проблемы повышения качества продукции. Москва, 2006. С. 148-152.

${ }_{5}^{4}$ Сиськов В.И. Статистические измерения качества продукции. Москва : Статистика, 1966. $167 \mathrm{c.}$

5 Джуран Дж.М. Ответственность руководящих работников промышленности за качество продукции. Стандартизация и качество. Москва : Комитет стандартов, 1966. С. 30-32.

${ }^{6}$ Фейгейбаум А. Контроль качества продукции. Москва : Экономика, 1986. 471 с.
} 
Other researchers, such as Zykov Yu.A., Matvieiev L.A., Polyshko S.P., Kozlov A.L., Arystov A.V., Mishyn V.M., define quality as "a set of properties that determine the degree of their compliance with a given specific need in fixed conditions of consumption" "T The most important criterion is to take into account the manifestation of product properties in specific consumption.

The ISO 8402-86 standard considers quality "as a combination of properties and characteristics of a product or service that give them the ability to satisfy specified or anticipated needs" 8 .

The identified needs are fixed in legal norms, standards, contracts, technical conditions of supplies and other documents. It is advisable to note that the above requirements are: requirements that are specified at the conclusion of the contract, requirements of regulatory documents for the implementation of environmental conditions. Failure to comply with most of the established requirements leads to administrative or legal liability. Estimated needs should be identified and determined (results of market research, new developments, consumer demand formation, etc.). It can be aesthetic requirements, the accordance of products to fashion, consumer preferences, national and cultural characteristics ${ }^{9}$.

In accordance with the international standard ISO 9000: 2000, quality is "the degree to which the totality of the characteristics of a product, process or system meets needs or expectations that are established, predictable or required". According to the standard DSTU ISO 9000: 2007, quality is "the degree to which the set of characteristics of an object meets the requirements of interested parties" $"$.

So, speaking about the concept of quality, it is necessary to note that the main place is given to needs. It should not be forgotten that the needs of consumers are unstable and constantly changing. Even when the product parameters can clearly correspond to the normative and technical documentation, however, the requirements of consumers change and the quality with constant parameters become worse or be completely lost.

But almost all authors in today's conditions emphasize that quality is the property of products to satisfy consumer needs.

\footnotetext{
7 Аристов О.В., Мишин В.М. Качество продукции : Учебное пособие. Москва : Издательство стандартов, 1982. 142 с.

${ }^{8}$ Управление качеством продукции. ИСО 9000-9004, ИСО8402. Москва : Изд-во стандартов, 1988.

${ }^{9}$ Шаповал М.I. Менеджмент якості : підручник. Київ : Т-во «Знання» КОО, 2001. 475 с.

${ }^{10}$ ДСТУ ISO 9000:2007 Системи управління якістю. Основні положення та словник термінів (ISO 9000:2005, IDT). Чинний від 01.01.2008. Київ : Держспоживстандарт України, 2008. 28 с.
} 
That is, product quality is directly related to customer satisfaction. In the conditions of market relations, the value of needs and their research should take a central place, because it is impossible to study the quality of products outside of existing social needs due to the fact that there is a close relationship between these two categories.

The state of needs or their satisfaction is closely related to quality indicators that quantitatively characterize the properties of products, therefore, when classifying needs, we can rely on the classification of indicators of production quality. Existing consumer needs Rebryn Yu.I. "classifies into several categories that differ from each other by temporary factors of action: basic, which are the main and objective when choosing a product, and additional ones that reflect the subjective desires of consumers" $"$.

Speaking about the current state of the interdependence of such concepts as product quality and need, it is worth noting that quite often an insufficiently high level of production quality depends on unexplored needs both in assortment and in the saturation of demand with specific goods. Therefore, the study of the today's and future needs is the first step in solving the problem of improving production quality.

From the various characteristics of product quality, a set of properties that determine its suitability to satisfy certain needs is distinguished. Each individual property of a product is an objective feature that can show itself in its creation, turnover and consumption, and is characterized by certain indicators. That is, product quality is evaluated on the basis of a quantitative measurement of its defining properties, and modern science and practice have developed a system for the quantitative evaluation of product properties and have given quality indicators ${ }^{12}$.

The quality indicator according to DSTU 2925-94 is interpreted as "a quantitative characteristic of one or more properties of products that make up its quality, which is considered relative to certain conditions of its creation and usage or consumption". The property of a production is "an objective feature of a product that may show itself during its creation, usage or consumption"13.

\footnotetext{
${ }^{11}$ Ребрин Ю.И. Управление качеством : Учебное пособие. Таганрог : Изд-во ТРТУ, 2004. 174 с.

${ }^{12}$ Боженко Л., Гутта О.Й. Управління якістю, основи стандартизації та сертифікації продукції : навчальний посібник. Львів, 2001. 176 с.

13 ДСТУ 2925-94. Якість продукції. Оцінювання якості. Терміни та визначення. Чин. від 01.01.1996. Київ : Держстандарт України, 1995. 25 с.
} 
Depending on the characteristics qualities, the indicators are divided into: goods purpose indicators, reliability indicators, indicators of productibility, indicators of standardization and unification, ergonomic indicators, aesthetic indicators, indicators of transportability, patent and legal indicators, environmental indicators, safety indicators ${ }^{12}$.

By the methods of determining the values of indicators, the authorsscientists distinguish: measuring, based on information obtained using technical measuring instruments; registration, based on the use of information obtained by counting the number of specific events; a calculation method in which the values of quality indicators are found using calculations with formulas, models, and other mathematical dependencies; the organoleptic method - is a method where instead of measuring tools are used the senses of experts; survey method, which can be applied in various forms: sociological and expert. The sociological method consists in using mass surveys of consumers or users of products and processing of their results by experts. An expert method of measuring quality indicators is to determine the quality indicators of products by experts.

Production quality can be evaluated by determining the level of quality. According to DSTU 2925-94 "Product quality. Quality evaluation" terms and definition of production quality level are defined as "relative characteristics of production quality, based on a comparison of the values of estimated indicators of production quality with the basic values of the relevant indicators." ${ }^{\text {12. }}$ Quality evaluation is a systematic examination that allows you to understand how the object is able to fulfill the established requirements. Failure to comply with established requirements is a noncompliance. To eliminate the causes of the existing noncompliances, organizations carry out corrective actions.

So, each product has a set of properties, their combination determines quality indicators, that is, quality indicators consist of quantitative characteristics of product properties.

Modern science has identified the following methods for evaluating the level of production quality - differential, complex, mixed, which allow us to evaluate the quality of products by comparing the measured values of quality indicators with basic indicators. The differential method of determining the level of product quality is to find individual unit indicators of its quality with the corresponding set of values of the corresponding basic quality indicators. A comprehensive method for determining the level 
of production quality is to compare the so-called complex indicators of the quality level instead of single ones, as in the differential method. The statistical method for determining the level of product quality, which is used in serial and mass production, is distinguished by periodically selecting a certain group of products, measuring their quality indicators and based on processing the results of the development of measures to ensure the product quality level specified in the technical requirements. ${ }^{14}$

It is worth noting that the disadvantage of the differential method of evaluating the quality level is the difficulty in deciding on the values of many individual quality indicators, since there can be an infinitely large number of these quality indicators. It is also difficult to evaluate the overall level of quality, since with the differential method it can only be confidently asserted that a baseline level has been achieved for some quality indicators and for others are not.

The disadvantage of the complex method is that a generalized quality indicator may not fully take into account all the essential properties of the product. The methodology of a comprehensive evaluation of the quality level is based on the condition of the unequal importance of individual useful properties that are compared among themselves. The disadvantage is the difficulty in accurately determining the importance of these properties. Also, to the disadvantages of the complex method can be added the possibility of "covering" a low level of some properties with a higher level of others.

The disadvantages of expert methods include the fact that the objectivity of the expert evaluation and its accuracy depends mainly on the qualifications of the expert. It is also difficult to find an error in the decision of an expert. Expert methods are quite laborious. The disadvantage is also the low recoverability of the results, since the evaluations made by the expert are influenced by a number of factors of an unstable compositions: age, gender, health status, and even part of the day when a decision is made ${ }^{15}$.

In product development, great importance is given to optimizing its quality indicators.

Shapoval M.I. determines that "such characteristics of quality indicators are called optimal, when the greatest effect is achieved from the

14 ДСТУ 2925-94. Якість продукціі. Оцінювання якості. Терміни та визначення. Чин. від 01.01.1996. Київ : Держстандарт України, 1995. 25 с.

15 Ткачук Л.М., Калугаряну Т.К. Якість продукції: методологічні та прикладні аспекти. Ефективна економіка. 2013. № 5. URL: http://nbuv.gov.ua/UJRN/efek_2013_5_20 
usage or consumption of the production at given costs for its creation and usage or consumption, or the desired effect at minimum costs, or the maximum ratio of effect to cost. In the case when at the given costs per unit of production the best characteristic of the generalized quality indicator, which characterizes the maximum effect from the operation or consumption of the product, is determined, it is considered as an optimization criterion, and the specified costs are limitations during optimization. Determining the optimal values of the characteristics of quality indicators makes sense only if the optimization criterion is established and the restriction is indicated"16.

The optimal values of the characteristics of quality indicators do not necessarily relate to real-life products; they can be determined by calculation for newly developed or even hypothetical production with the value of characteristics of quality indicators that can actually be achieved. In the latter case, such calculated values of the optimal characteristics of quality indicators are used as the basis for comparing with them the corresponding characteristics of the quality indicators of existing product samples. The optimal values of the characteristics of indicators of product quality in the presence of an objective function and restrictions on costs or effect are determined by linear and non-linear programming, dynamic programming, game theory and statistical decisions, optimal-control theory and other mathematical methods described in the special literature.

In a market economy, a system for evaluating production quality should most closely match the characteristics of market relations between producers and consumers. To do this, it is advisable to solve the following issues:

firstly, it concerns an objective evaluation of production quality at various stages of interaction between developers, manufacturers and consumers of products, taking into account the relationship between quality, quantity and price;

secondly, the ability to quickly obtain all the necessary objective data on product quality, its technical level and competitiveness at any stage of the product life cycle.

A modern quality evaluation system at the enterprise, regardless of the form of ownership and scale of production, should optimally combine actions, methods and means that ensure, on the one hand, the manufacture

\footnotetext{
${ }^{16}$ Шаповал М.І. Менеджмент якості : підручник. Київ : Т-во «Знання» КОО, 2001. 475 с.
} 
of products that meet the needs of the market, and on the other, the development of new products that can satisfy future needs the market.

So that the production have success in the market and can successfully compete in it, it must meet the needs of the consumer. To do this, on the one hand, the state must take into account the needs of the market when developing quality standards, and on the other hand, the manufacturer of the products themselve. Meeting needs requires the manufacture of products of a certain quality and quantity. The gap between needs and manufactured production in terms of quality and market saturation should be the basis for managerial decisions on state management of production quality. In order for a product to be of high quality, the needs of today should be laid in it, however, besides this, the manufacturer should remember that quality is a dynamic concept, it has a change in time, as consumer needs change - so the quality changes. Quality as a degree of compliance with consumer needs is constantly changing over time with the changing requirements and needs of consumers, and what was considered a quality product yesterday may not correspond to a technical innovation that can better satisfy the needs of consumers who have already changed. Quality as an economic category is associated with meeting the needs of consumers, while products have many properties, by measuring which we can evaluate quality. As a review of sources shows, in terms of quality evaluation, that is, indicators and methods are analyzed, today there is no clear concept for quality evaluation.

The modern system of quality evaluation at the enterprise, regardless of the form of ownership and scale of production activities, should optimally combine actions, methods and tools that ensure the manufacture of products that will satisfy the needs of the market, that is, should focus on the needs of consumers and their dynamics.

Improving the level of production quality is an important task of both a single enterprise and the state as a whole. Today, production quality, as already mentioned, is manifested through the properties and level of customer satisfaction.

Product quality is manifested through properties, properties, in turn, can be represented through product characteristics, which can be measured using quality indicators. Each product is described by many quality indicators that characterize it. In addition, modern science has proposed methods for evaluating the level of production quality - differential, 
complex, mixed, statistical, measuring, expert, organoleptic, sociological, that allow you to evaluate quality by comparing the measured values of quality indicators with basic indicators. So, using the proposed indicators and methods for evaluating them, you can evaluate the quality by comparing its indicators with the baseline. However, they allow you to evaluate quality only now, at the time of manufacture and transfer to operation, but the problem is that quality is not a constant value, and tends to change over time with changing needs and requirements of consumers, which give quality a final evaluation. Therefore, the disadvantage of existing methods is that they do not take into account the time factor in evaluating quality, that is, they do not make it possible to evaluatie the degree of customer satisfaction with products during the time change.

It is worth noting that the reliability indicators (reliability, storage, maintainability, durability) indicate the preservation of properties over time. These indicators characterize the property of the product to perform its functions by maintaining operational indicators within the established limits during the given period of time established in the technical documentation. However, these indicators are not able to comprehensively evaluate the quality, especially since the ability to maintain product properties is carried out within the period established by technical documents.

So, today, firstly, there is no clear concept for evaluating quality, and secondly, these methods and indicators do not allow us to evaluate quality, considering the time factor, therefore, there is a need to develop a method for evaluating quality not only now, but also over time, that is, to find cumulative quality for a certain time interval.

\section{Equipment reliability qualification}

As already noted, the quality of the object is manifested primarily because of its properties. To the extent that a set of these properties will satisfy the needs of consumers and product quality will manifest itself.

We will consider one of such important properties as reliability and trace how reliability changes over time.

According to the source, ${ }^{17}$ as the reliability indicators are taken the probability of uptime, average time between failures and the intensity of failures. Reliability is a quality indicator that requires further research. It is

17 ДСТУ 2925-94. Якість продукції. Оцінювання якості. Терміни та визначення. Чин. від 01.01.1996. Київ : Держстандарт України, 1995. 25 с. 
this indicator that can be considered as a property of the product to maintain its parameters over time, which is the main characteristic for industrial equipment, because for any enterprise it is important that the equipment has as few failures and consequently downtime. So, reliability is the main property of industrial equipment. In this regard, let us dwell on the evaluation of the reliability indicator.

Reliability is one of the properties of the product to keep in time and the specified permissible limits of all parameters of their quality in accordance with the specified conditions for their use, repair, storage and transportation. In other words, reliability includes such product quality indicators as reliability in the performance of its functions, maintainability, in case of elimination of the causes of temporary loss of the specified quality of the products and storage for a given time ${ }^{18}$.

Reliability is closely linked to risk. So according to the source ${ }^{19}$ in general terms, the risk of a process (system) is defined as the property of a system under the influence of internal and external factors to switch from a state of normal functioning to a state of failure. And reliability is understood as the possibility of failure-free operation of a system (process) for a given period of time. Therefore, according to the methodology for evaluating the reliability and risk of the system described in the work of M. M. Klymenyuk, I.A. Bryzhan "Risk Management in the Economy" we perform calculations to evaluate the reliability of the production process on the example.

So, reliability is the main property of the production process, so its quality must be evaluated precisely by the reliability indicator.

In accordance with the methodology for evaluating the reliability and risk of the system, we perform calculations to evaluate the reliability of the industrial production process.

To determine the reliability of the production process, we consider its functioning on a finite time interval $(0, \mathrm{~L})$. During this time, it may be in working $-\mathrm{E}_{1}$ or non-working $-\mathrm{E}_{0}$ states.

An estimate of the reliability of the system over the time interval $(0, \mathrm{~L})$ is $^{20}$ :

\footnotetext{
${ }^{18}$ Боженко Л., Гутта О.Й. Управління якістю, основи стандартизації та сертифікації продукції : навчальний посібник. Львів, 2001. 176 с.

${ }^{19}$ Клименюк М.М., Брижань I.А. Управління ризиками в економіці : навчальий посібник. Київ : Просвіт, 2000. 256 с.

${ }^{20}$ Клименюк М.М., Брижань І.А. Управління ризиками в економіці : навчальий посібник. Київ : Просвіт, 2000. 256 с.
} 


$$
\mathrm{H}(1, \mathrm{~L})=\frac{r \times m}{L}
$$

$\mathrm{r}$ - the number of cases the system was in working condition, pcs;

$\mathrm{m}$ - the average duration of the system in working condition, 24-hour periods;

$\mathrm{L}$ - time interval during which the study was going, 24-hour periods.

At the same time, we accept that the number of cases the production process has been in working condition coincides with the number of failures since these states interchange. To determine the level of system reliability, it is necessary to collect data on the presence of this system in a state of failure or in operable state.

The calculations will be based on data of the DBK-1 reinforced concrete products factory, which produces reinforced concrete panels for the installation of panel houses. The main production process carried out by the plant is the production, stockpiling and loading of panel carriers with the products necessary for construction and installation departments. The normal course of this process is to load panel carriers with the necessary products as they arrive at the finished goods warehouse of the plant - this is the operating condition of the system. If at the time of arrival of the vehicle in the warehouse there is no product of the necessary nomenclature, then the car is in idle period, that is, the system is inoperative (failure condition).

To evaluate the reliability of the production process, its operation was monitored for the number of failures in work for eight quarters.

After a study conducted in the first quarter, we have the following results (Table 1).

Table 1

Information about the failure of the production process in the 1 quarter

\begin{tabular}{|l|c|c|c|c|c|c|c|c|}
\hline Failure serial number & 1 & 2 & 3 & 4 & 5 & 6 & 7 & 8 \\
\hline Duration of failure, 24-hour period & 0,1 & 0,3 & 0,2 & 0,5 & 0,5 & 0,2 & 0,6 & 1 \\
\hline
\end{tabular}

Source: compiled by the author individually 
From the above table it follows that on the time interval (0.90) the production process was in a state of failure 8 times and this state lasts 3.4 24-hour periods.

Duration of system operation is

$$
\tau=90-3,4=86,6 \text { 24-hour period. }
$$

The average working condition is

$$
\mathrm{m}=\frac{86,6}{8}=10,825 \text { 24-hour period. }
$$

Reliability rating is

$$
\mathrm{H}(1,90)=\frac{r \times m}{L}=\frac{8 \times 10,825}{90}=0,96
$$

So, the reliability of the production process for the study period is 0.96 or $96 \%$.

Information on the downtime of the production process for the second quarter is shown in Table 2.

Table 2

\section{Information about the failure of the production process} in the 2 quarter

\begin{tabular}{|l|c|c|c|c|c|c|c|c|}
\hline Failure serial number & 1 & 2 & 3 & 4 & 5 & 6 & 7 & 8 \\
\hline Duration of failure, 24-hour period & 0,6 & 0,3 & 0,4 & 0,9 & 1,6 & 0,8 & 0,4 & 0,7 \\
\hline
\end{tabular}

Source: compiled by the author individually

From the above table it follows that on the time interval $(0.90)$ of the production process it was in a state of failure 8 times and this state lasts 5.7 24-hour periods.

Duration of system operation is

$$
\tau=90-5,7=84,3 \text { 24-hour period. }
$$

The average working condition is

$$
\mathrm{m}=\frac{84,3}{8}=10,537 \text { 24-hour period. }
$$


Reliability rating is

$$
\mathrm{H}(1,90)=\frac{r \times m}{L}=\frac{8 \times 10,537}{90}=0,94
$$

So, the reliability of the production process for the study period is 0.94 or $94 \%$.

Information on the downtime of the production process for the third quarter is shown in Table 3.

Table 3

\section{Information about the failure of the production process in the 3 quarter}

\begin{tabular}{|l|c|c|c|c|c|c|c|c|c|}
\hline Failure serial number & 1 & 2 & 3 & 4 & 5 & 6 & 7 & 8 & 9 \\
\hline $\begin{array}{l}\text { Duration of failure, } \\
\text { 24-hour period }\end{array}$ & 1,2 & 0,6 & 0,5 & 1,3 & 0,5 & 0,4 & 1,7 & 1 & 0,7 \\
\hline
\end{tabular}

Source: compiled by the author individually

From the above table it follows that on the time interval (0.90) of the production process it was in a state of failure 9 times and this state lasts 7.9 24-hour periods.

Duration of system operation is

$$
\tau=90-7,9=82,124 \text {-hour period. }
$$

The average working condition is

$$
\mathrm{m}=\frac{82,1}{9}=9,12 \text { 24-hour period. }
$$

Reliability rating is

$$
\mathrm{H}(1,90)=\frac{r \times m}{L}=\frac{8 \times 9.12}{90}=0,91
$$

So, the reliability of the production process for the study period is 0.91 or $91 \%$.

Information on the downtime of the production process for the fourth quarter is shown in Table 4. 
Table 4

Information about the failure of the production process in the 4 quarter

\begin{tabular}{|l|c|c|c|c|c|c|c|c|c|c|}
\hline Failure serial number & 1 & 2 & 3 & 4 & 5 & 6 & 7 & 8 & 9 & 10 \\
\hline $\begin{array}{l}\text { Duration of failure, } \\
\text { 24-hour period }\end{array}$ & 0,3 & 1,3 & 0,4 & 0,6 & 1,3 & 0,1 & 1,6 & 0,9 & 1,2 & 0,8 \\
\hline
\end{tabular}

Source: compiled by the author individually

From the above table it follows that on the time interval $(0.90)$ of the production process it was in a state of failure 10 times and this state lasts 8.5 24-hour periods.

Duration of system operation is $\tau=90-8,5=81,5$ 24-hour period.

The average working condition is

$$
\mathrm{m}=\frac{81,5}{10}=8,15 \text { 24-hour period }
$$

Reliability rating is

$$
\mathrm{H}(1,90)=\frac{r \times m}{L}=\frac{8 \times 8.15}{90}=0,90
$$

So, the reliability of the production process for the study period is 0.90 or $90 \%$.

Information on the downtime of the production process for the fifth quarter is shown in Table 5.

Table 5

\section{Information about the failure of the production process in the 5 quarter}

\begin{tabular}{|l|c|c|c|c|c|c|c|c|c|c|c|}
\hline $\begin{array}{l}\text { Failure serial } \\
\text { number }\end{array}$ & 1 & 2 & 3 & 4 & 5 & 6 & 7 & 8 & 9 & 10 & 11 \\
\hline $\begin{array}{l}\text { Duration of failure, } \\
\text { 24-hour period }\end{array}$ & 0,7 & 0,7 & 1,8 & 0,8 & 1 & 1 & 0,9 & 1,3 & 1,2 & 1,4 & 1,5 \\
\hline
\end{tabular}

Source: compiled by the author individually 
From the above table it follows that on the time interval $(0.90)$ of the production process it was in a state of failure 11 times and this state lasts 12,3 24-hour periods.

Duration of system operation is

$$
\tau=90-12,3=77,7 \text { 24-hour period. }
$$

The average working condition is

$$
\mathrm{m}=\frac{77,7}{11}=7,06 \text { 24-hour period. }
$$

Reliability rating is

$$
\mathrm{H}(1,90)=0,86
$$

So, the reliability of the production process for the study period is 0.86 or $86 \%$.

We will carry out similar calculations for following periods. In total for eight quarters we have the following indicators of the reliability of the production process (Table 6).

Table 6

Information on changes in reliability over a period of 8 quarters

\begin{tabular}{|l|c|c|c|c|c|c|c|c|}
\hline $\begin{array}{l}\text { Serial number } \\
\text { of the quarter }\end{array}$ & 1 & 2 & 3 & 4 & 5 & 6 & 7 & 8 \\
\hline Reliability & 0,96 & 0,94 & 0,91 & 0,9 & 0,86 & 0,85 & 0,84 & 0,82 \\
\hline
\end{tabular}

Source: compiled by the author individually

So, we found indicators of the reliability of the production process over 8 quarters and we can trace the trend towards a decrease in the values of the reliability indicator from 0.96 to 0.82 . We will depict this trend in Figure 8.

Having the above indicators of changes in reliability over time, we make forecast values for 7 periods ahead. To do this, we construct five types of trending models and define the determination coefficients for each of them.

In Figure 9, we build a reliability forecast by constructing a linear trend, we find the value of the coefficient of determination. 


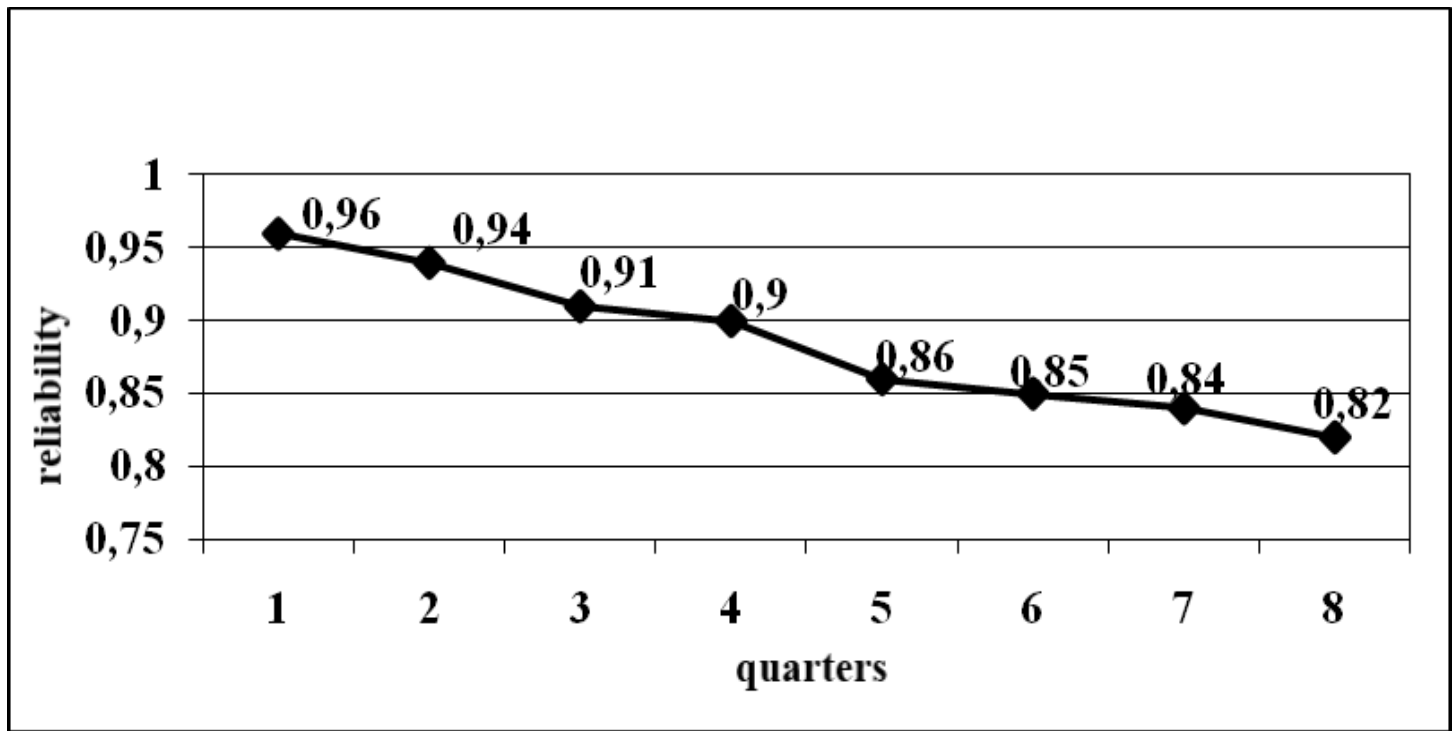

Figure 8. The reliability dynamics of the production process over 8 quarters

Source: compiled by the author individually

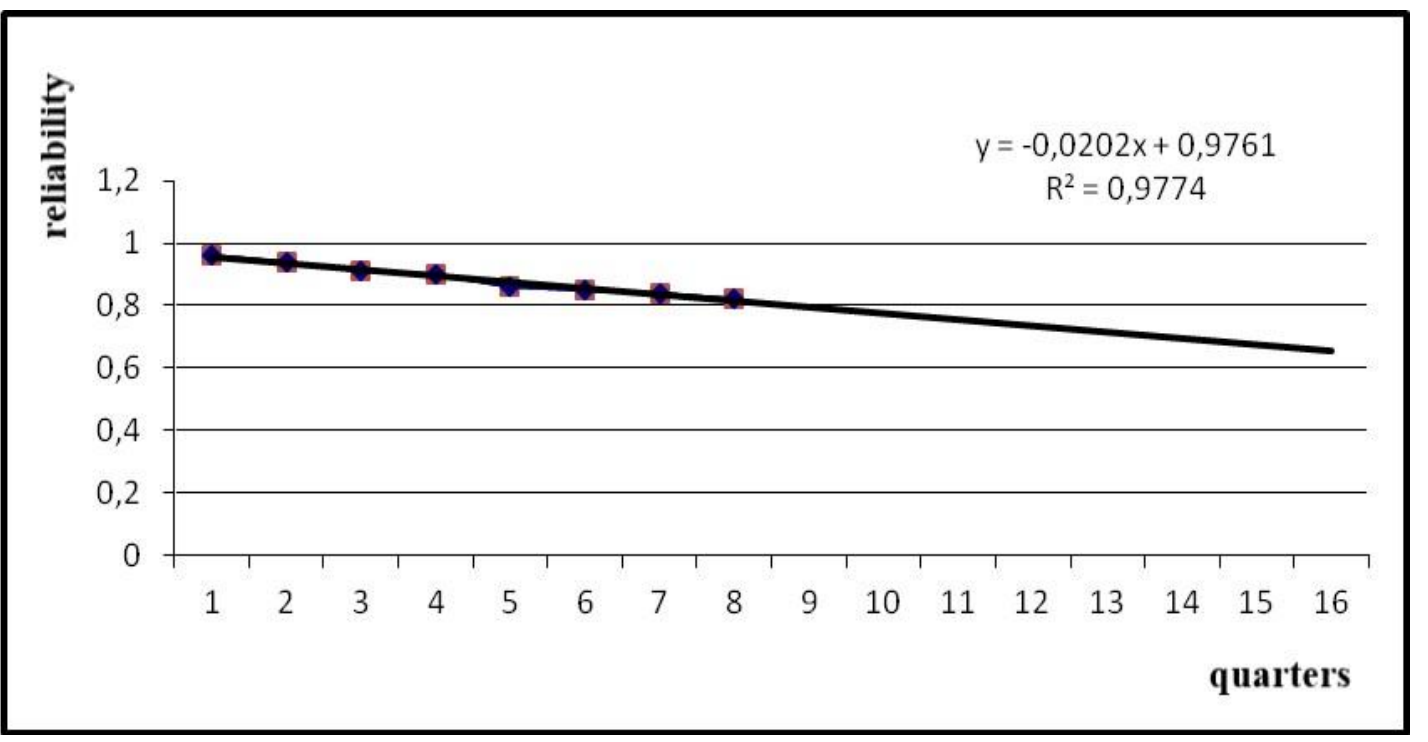

Figure 9. Reliability prediction by building a linear trend

Source: compiled by the author individually

In Figure 10, we build a reliability forecast using a logarithmic trend, we find the value of the coefficient of determination. 


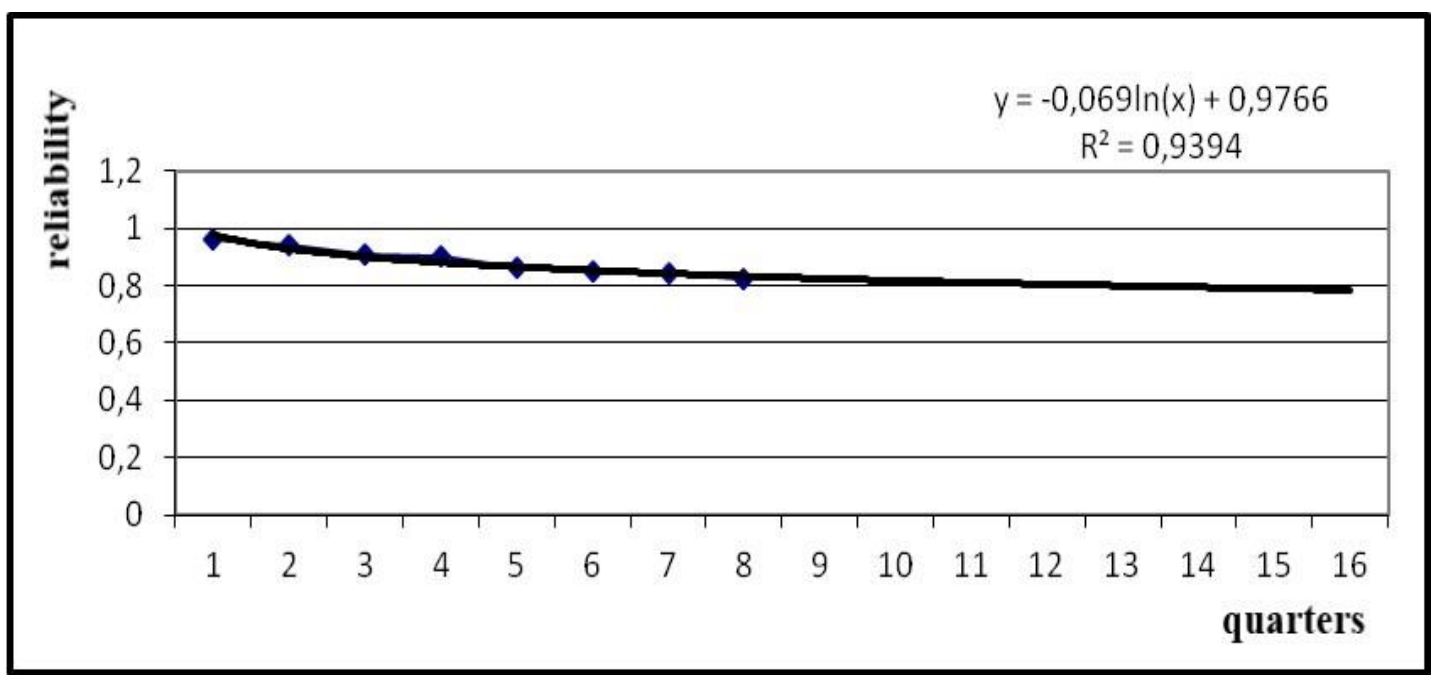

Figure 10. Reliability prediction by building a logarithmic trend

Source: compiled by the author individually

In Figure 11, we build a reliability forecast using a second-order parabola, we find the value of the coefficient of determination.

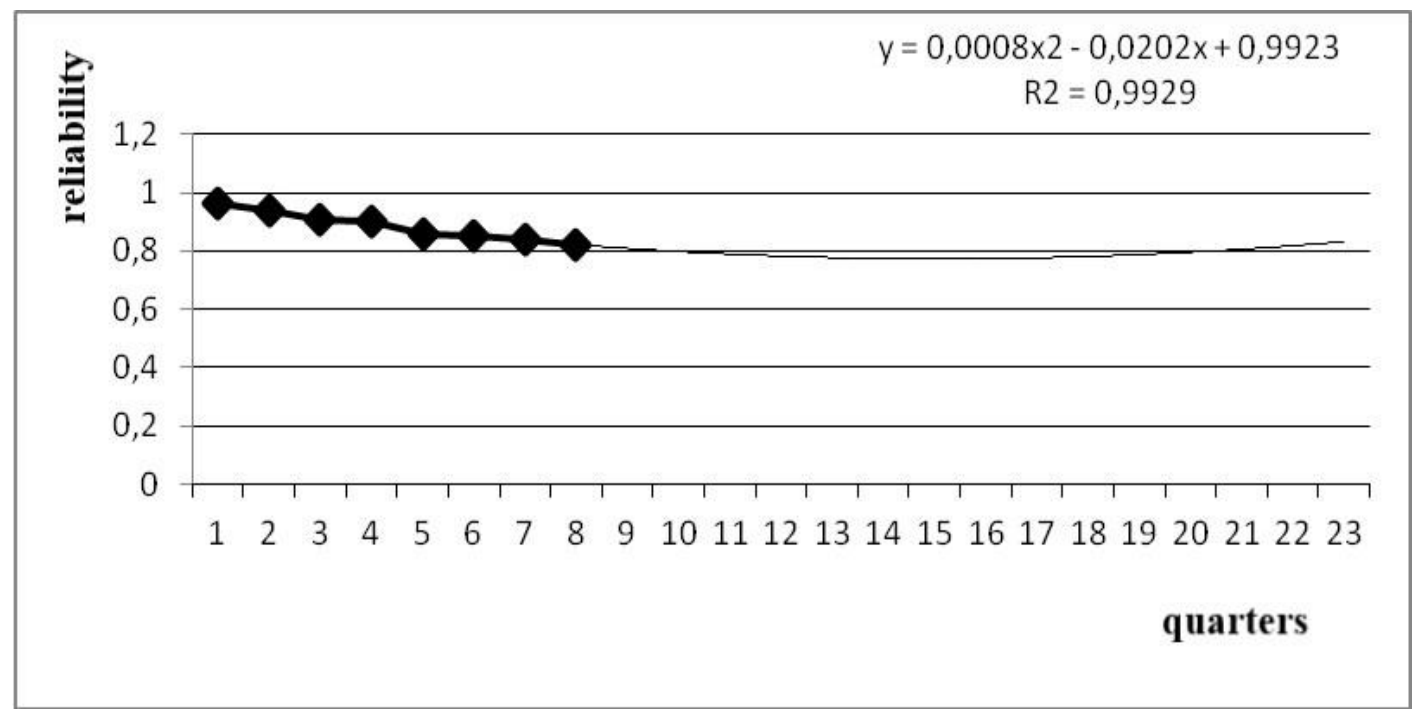

Figure 11. Reliability prediction by parabola of 2 order

Source: compiled by the author individually

In figure 12 , we build a reliability forecast using a power-law trend, we find the value of the coefficient of determination. 


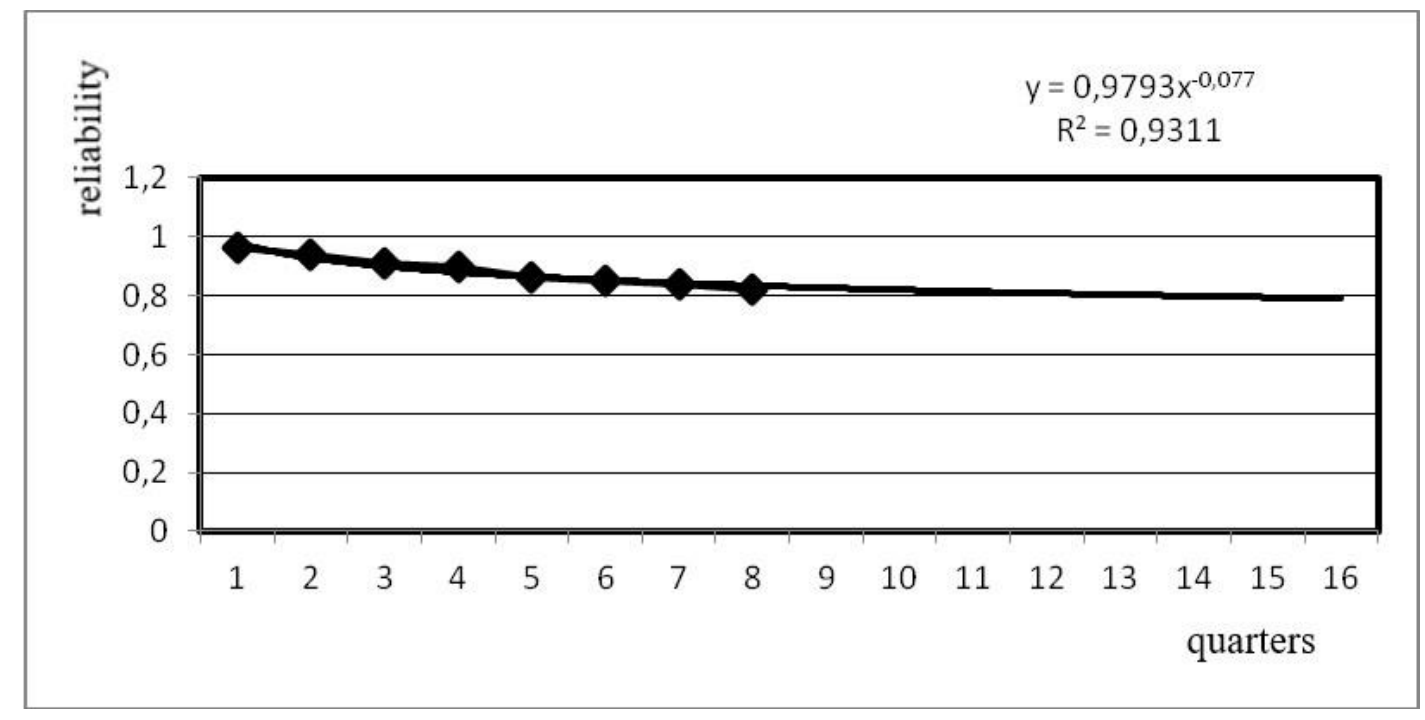

Figure 12. Reliability prediction by building a power-law trend Source: compiled by the author individually

In Figure 13, we construct a reliability forecast using an exponential trend, we find the value of the coefficient of determination.

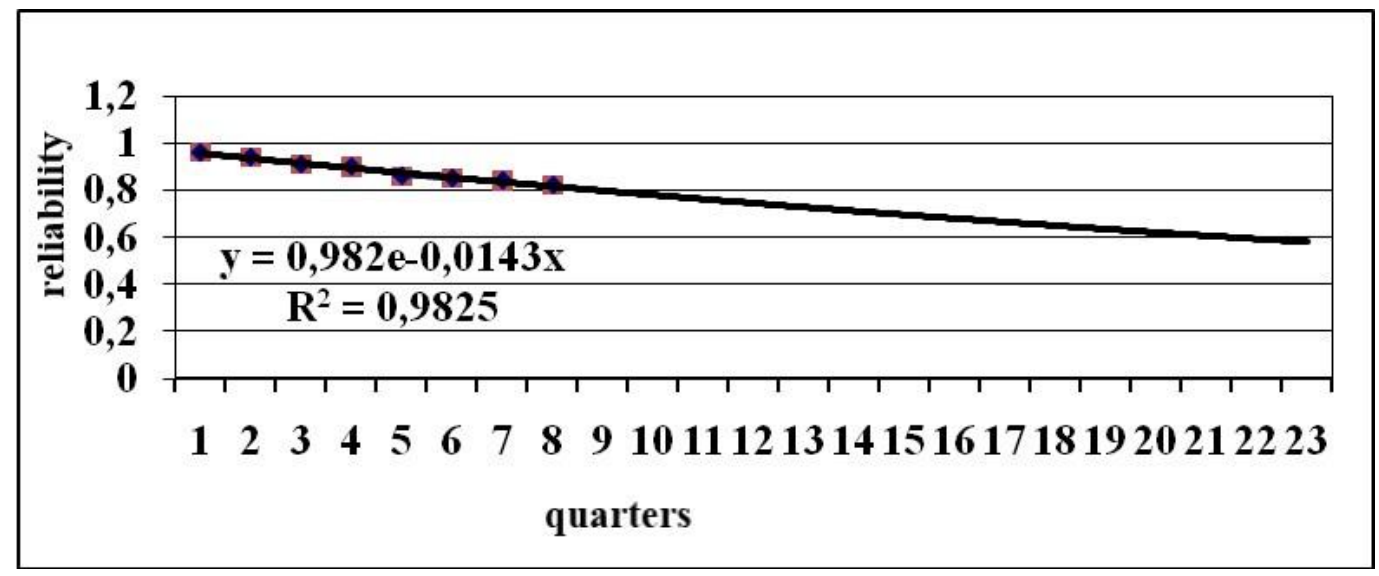

Figure 13. Reliability prediction by building an exponential trend Source: compiled by the author individually

The construction of trending models of five types and determination of the coefficient of determination for each of them gave the results, which are presented in Table 7.

Based on the value of the determination coefficient for forecasting the reliability indicator, you should choose a trend model in the form of a parabola of 2 order, since this indicator is the highest and is 0.9929. However, when forecasting future values for this model, we observe a 
significant increase in the reliability indicator, which cannot be in reality (Fig. 11).

Table 7

\section{Information about the constructed trend models for the reliability indicator}

\begin{tabular}{|l|l|l|}
\hline \multicolumn{1}{|c|}{ Type of trend } & \multicolumn{1}{|c|}{ Function } & \multicolumn{1}{c|}{$\begin{array}{c}\text { Determination } \\
\text { coefficient } \mathrm{R}^{2}\end{array}$} \\
\hline linear & $y=-0,020 x+0,976$ & 0,977 \\
\hline logarithmic & $y=-0,061 \operatorname{Ln}(x)+0,976$ & 0,939 \\
\hline parabola of 2 order & $y=0,0008 x^{2}-0,0202 x+0,9923$ & 0,9929 \\
\hline exponential & $y=0,982 e^{-0,0143 x}$ & 0,9825 \\
\hline power-law & $y=0,979 x^{-0,07}$ & 0,931 \\
\hline
\end{tabular}

Source: compiled by the author individually

Therefore, we consider it appropriate to use an exponential trend model (Fig. 13).

Having modeled the reliability indicator, the most reliable forecast was found and, accordingly, the function for further reliability studies.

For a better evaluation of reliability, we suggest taking the total (cumulative) reliability indicator for the affected period. Thus, we will have an evaluation of reliability by finding cumulative reliability. Cumulative quality, in turn, is the area from the abscissa axis to the function on a given time interval, or in other words, it is the sum of interval quality levels on a given time interval.

This method can be proposed by the state for both state and other business entities.

\section{CONCLUSIONS}

Therefore, quality as an economic category is associated with satisfying the needs of consumers, while products have many properties, by measuring which we can evaluate quality. As a review of sources shows, in evaluating quality, that is, the analyzed indicators and methods, today there is no clear concept for evaluating quality, and these methods and indicators do not allow to evaluate quality, from the perspective of time. Using the proposed indicators and methods for evaluating them, you can evaluate the quality by comparing its indicators with the baseline. 
However, they allow you to evaluate quality only now, at the time of manufacture and transfer to operation, but the problem is that quality is not a constant value, and it tends to change over time with changing needs and requirements of consumers, which give quality a final evaluating. Therefore, the disadvantage of existing methods is that they do not take into account the time factor in evaluating quality, that is, they do not make it possible to evaluate the degree of customer satisfaction with products during a time change. So, a method for evaluating quality by modeling a reliability indicator as the main indicator in the system of quality indicators is proposed. At the same time, we note that the time factor occupies an important place in evaluating quality, since quality is not a constant value, and it tends to change over time. For a better evaluation of reliability, we suggest taking a cumulative reliability indicator for the affected period.

A method for evaluating quality by modeling a reliability indicator as the main indicator in a system of quality indicators is proposed. We take into account the time factor, which occupies an important place in evaluating quality, since quality is not a constant value, and it tends to change over time. For a better evaluation of reliability, we suggest taking a cumulative quality indicator for the affected period, which is the area from the abscissa to the function on a given time interval, or in other words, this is the sum of interval quality levels on a given time interval. The use of this method can be proposed by the state for both state and other business entities.

\section{SUMMARY}

Quality as an economic category is associated with meeting the needs of consumers, while products have many properties that can be measured by evaluating quality. The state of needs and their satisfaction is closely related to quality indicators that quantitatively characterize its properties. Ensuring the effectiveness of quality management at all stages of the product life cycle is inextricably connected with quality evaluation. Evaluating the level of product quality is the basis for decision-making in the quality management system. It is understood that quality of products under the influence of scientific and technological progress and consumer requirements tends to change over time, in connection with which there is a need to evaluate the quality of products, based on a promising level that takes into account the priority areas and pace of development of science 
and technology and consumer preferences. The reliability indicator is studied as one of the main indicators of quality evaluation in the system.

\section{REFERENCES}

1. Гегель Г.В.Ф. Логіка. В кн. : Гегель Г.В.Ф. Твори. Т.І.М. - Л.: Держвидав, 1929.

2. Гличев А.В., Панов В.П., Азгальдов Г.Г. Что такое качество? Москва : Экономика, 1968. 135 с.

3. Соболева М.А. Роль стандартизации в решении проблем качества промышленной продукции в США. Экономические проблемы повышения качества продукиии. Москва, 2006. С. 148-152.

4. Сиськов В.И. Статистические измерения качества продукции. Москва : Статистика, 1966. 167 с.

5. Джуран Дж.М. Ответственность руководящих работников промышленности за качество продукции. Стандартизаџия $u$ качество. Москва : Комитет стандартов, 1966. С. 30-32.

6. Фейгейбаум А. Контроль качества продукции. Москва : Экономика, 1986. $471 \mathrm{c.}$

7. Аристов О.В., Мишин В.М. Качество продукции : Учебное пособие. Москва : Издательство стандартов, 1982. 142 с.

8. Управление качеством продукции. ИСО 9000-9004, ИСО8402. Москва : Изд-во стандартов, 1988.

9. Шаповал М.I. Менеджмент якості : підручник. Київ : Т-во «Знання» КОО, 2001. 475 с.

10. ДСТУ ISO 9000:2007 Системи управління якістю. Основні положення та словник термінів (ISO 9000:2005, IDT). Чинний від 01.01.2008. Київ : Держспоживстандарт України, 2008. 28 с.

11. Ребрин Ю.И. Управление качеством : Учебное пособие. Таганрог : Изд-во ТРТУ, 2004. 174 с.

12. Боженко Л., Гутта О.Й. Управління якістю, основи стандартизації та сертифікації продукції : навчальний посібник. Львів, 2001. $176 \mathrm{c}$.

13. ДСТУ 2925-94. Якість продукції. Оцінювання якості. Терміни та визначення. Чин. від 01.01.1996. Київ : Держстандарт України, $1995.25 \mathrm{c}$. 
14. Ткачук Л.М., Калугаряну Т.К. Якість продукції: методологічні та прикладні аспекти. Ефективна економіка. 2013. № 5. URL: http://nbuv.gov.ua/UJRN/efek_2013_5_20

15. Клименюк М.M., Брижань I.А. Управління ризиками в економіці : навчальий посібник. Київ : Просвіт, 2000. 256 с.

Information about the author: Grudtsyna Y. V. $\mathrm{PhD}$, Associate Professor, Department of Management and International Economic Relations V. I. Vernadsky Taurida National University 33, John McCain str., Kyiv, 02000, Ukraine 